\title{
良導絡と循環器疾患
}

\section{§ はじめに}

昨年10月高血圧学会が仙台にありましてまい りました。仙台は良い町で私は大変好きであり ます。庄禅寺通りという並木のきれいな通りが ありましてその通りに面して県民会館がありま す。そてで学会が行われたのでありますがレニ ン、アンギオテンシン、アルドステロン系とか キニン、カリクレイン系とかプロスタグランデ ィンとか体液性昇圧、降圧機構に関する生化学 的演題でうずめつくされて居りました。県民会 館を過ぎてちょっとゆくとよつかどにあたりま す。その一角に操体法で有名な橋本先生の診療 室があります。かねてから一度訪問したいと思 って居りましたのでおもいきって伺いました。 診療室の $1 / 3$ にタタミがしいてありましてフロ ア一の方はベッドが一つ、受付の女の子と助手 1 人居りまして先生は大きな火鉢のそばでタバ コをくゆらしてみて居ます。私む先生に直接や ってもらいました。まずうつぶせにベッドの上 にねかされまして下肢を膝関節から曲げる。体 につかない。やって居る中につく様になるそう であります。かえるの様に下肢をまげて身体に つける運動の他いくつかの方法をやってもらい ました。すっきりした感じで先生の診療室を辞 したのでありますが近くに仙台湾という鮮魚料 理屋があって仙台にくる度による店でててでカ レーのさしみと地酒ですっかりいい気持になり ました。ホテルにすどってよいがさめてさて一 体近代医学とは何だろうと考えました。一方は 学会の様にミクロの生化学の世界を又一方橋本 先生の所では気持のよい方にまわして、何回も

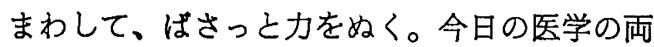
極端をまざまざとみせられたととでした。歪を なおすというととは良導絡に近い考え方であり まして心情的には好きであります。ミクロのみ
東京都今 井 力

方、マクロのみ方、両方とあ必要なのでありま しょう。

今日はむしろボデーから入ったマクロのみ方 について循環器疾患を対象にお話ししてみたい と思います。

\section{§ 低血圧症}

加藤の分類によれば症候性低血圧と体質性低 血圧とにわかれ体質性低血圧には塞愁訴性之愁 訴性とあります。われわれの対象となるのは愁 訴性体質性低血圧でありますが、どちらかとい うと虚証のものが多く弱刺激が適して居りま す。従って浅くさして針のみ、或は軽く通電す るのが原則であります。良導絡測定により調整 をまず行い、使用穴としては復溜 $\mathrm{F}_{3} 7$ 、足三里 $\mathrm{F}_{6} 9$ 、陽陵泉 $\mathrm{F}_{5} 11$ 、胃 5 穴、天枢 $\mathrm{F}_{6} 22$ 、腹結 $\mathrm{F}_{1} 14$ 、気海 $\mathrm{VM}_{5}$ 、膻中 VM16、堅俞 $\mathrm{F}_{4} 34$ 、 志室 $F_{4} 33$ 、脾俞 $F_{4} 40$ 、肝俞 $F_{4} 44$ 、心俞 $F_{4} 48$ 、 厥陰俞 $\mathrm{F}_{4} 50$ 、高㡱 $\mathrm{F}_{4} 51$ 、肩井 $\mathrm{H}_{5} 17$ 、天柱 $\mathrm{F}_{4}$ 59、風池 $\mathrm{F}_{5} 30$ 、百会VM30 を通常使用いたし ます。低血圧の場合は頸に問題のある事が多 く、ここを注意深くやり、筋肉のこりをとって おきます。又腰に問題があれば腰を、胃が弱け れば胃に重点をと随時取捨してやります。復溜 に浅くさしてゅっくりと50 60回雀啄する方法 あ大変効果があります。又復溜にお炎をするの あよいと思います。最初つづけて 3 回、次の週 は 2 回、次の週以後は週 1 回計 1 力月に 8 回で 大体良くなる様であります。薬物療法に良導絡 を併用いたしますと切れ味がよく大変よい適応 症であります。

漢方としては、苓桂求甘（胃アトニー合併）、 当㷌苟薬散 (婦人の虚症)、八味地黄丸 (堅虚)、 小柴胡湯（胸脇苦満）、葛根湯（肩こり）、人 参湯（胃弱）、真武湯（冷え症）の順に使用頻 度が多い。 


\section{§高血圧症}

私のところは高血圧症が多いのでありますが 全部に良導絡をやるわけではありませんで降圧 剂を長くつつけけていて安定しておればそのまま でありますが、つつうがする、屃がてる、どう きがするという方が中には居りますので良導絡 をやってみるととれらの愁訴がとれると同時に 血压の方す安定してくるととをしばしば経験い たします。又後にのへますが頸に問題がある場 合はそれをとってやると下らない血珐が下るよ うになります。良導絡調整はむろんであります が取穴部位は全般的にひろく求めるので百会 $\mathrm{HM} 26$ 、天柱 $\mathrm{F}_{4} 59$ 、肩井 $\mathrm{H}_{5} 17$ 、肝俞 $\mathrm{F}_{4} 48$ 、 脾俞 $\mathrm{F}_{4} 40$ 、三焦俞 $\mathrm{F}_{4} 36$ 、次露 $\mathrm{F}_{4} 23$ 、手三里 $\mathrm{H}_{6} 10$ 、風市 $\mathrm{F}_{5} 14$ 、足三里 $\mathrm{F}_{6} 9$ 、胃 5 穴、気海 VM5、とし、堅の合併症の場合は、志室復溜、 涌泉等をよくやり特に復溜乃至湧泉のお尒はし つてくやればかなり効果がみられます。腎性高 血圧で $2 \sim 3$ の病院でみはなされた患者に、も うこれしか方法がないといって炎をすすめた所 大変よくなって現在元気ではたらいて居りま す。奇跡的に効く場合がありますので困った時 はやってみるのも一方法です。脳・心・眼底等 の合併症に対してはその治療点を重点的に行い ます。高血圧の場合は坐位にして頭からやり、 低血圧の場合はねかせておいて下肢からはじめ るのが原則であります。又耳の降圧点を使用す るのすよいと思います。

漢方の使用目標としては実証、中間、虚証と わけて用いると便利。実証一三黄沮心湯（あ から顔、のほせ）、黄連解毒湯（あから顔、の ほ 骨牡蚛湯（胸脇苦満）、防風通聖散（太鼓腹）、 桃核承気湯（疾血）、桂枝伏苓丸（疾血）中 間・虚証より一七物降下湯（最小血圧が高 い）、防己黄灰湯（水ふとりの感じ）、温清飲 （皮屚の色つやか悪い）虚証一当㷌菏薬散 （虚弱な体質）、真武湯（足腰が冷える）、八 味丸（腎虚の場合）、肩とり、首筋のとりが特 に著明な場合は葛根湯、柴胡桂枝湯、柴胡桂枝 乾姜湯、加味道遥散等を併用する。

\section{§ 心疾息}

心不全は原因が心べんまく症、高血厈、心筋
症、バセドウ、老人性動脈硬化症等色々あっ て、原疾患の治療は勿論でありますが良導絡の 併用は好結果を得るととが多いと思います。

症例の 1 平○留○ 81才 せき、たんがつ つき朝方苦しいということで、S56年 8 月18日 来院。うっ血性心不全に心房細動を合併して居 ります。B・D160-94mmHg、下肢のむくみは

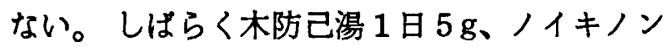
$3 \mathrm{Tab} / 1$ 日、ラシックス $1 \mathrm{Tab} / 1$ 日 及び抗生 物質で経過をみた。寒くなり、咳、痰が多くな り12月 1 日より郄門 $\mathrm{H}_{2} 6$ 、少海 $\mathrm{H}_{3} 7$ 置針低周波 15分を 1 週間に 1 回ずつ行い現在に到るまで計 50 回、経過良好。低周波置針時、モニタ-E C $\mathrm{G}$ でてゆくと、 R、T波の増高と $\mathrm{S}$ 一 T低下 が逆偟上昇してく。又その際血浆カテコール アミンの中、アドレナリンは不変であるがノル アドレナリンはやや増加の傾向である。交感神 経を電気刺激するとノルアドレナリンが増える という動物実験があるので交感神経を刺激する と考えてよいと思います。

症例の 2 宝○菊○ 76才 いきぎれ、夜中 に息苦しい、かせを昨年より、ひきっぱなしと いうことで来院。 B・D155-101 $\mathrm{mmHg}$ 、肝 3 横指、むくみ、心房細動をともなったうっ血性 心不全である。木防己湯 1 日 $5 \mathrm{~g} 、$ ラシックス $1 \mathrm{Tab} /$ 日、スローK $3 \mathrm{Tab} /$ 日、ヂゴキシン 1 $\mathrm{Tab} /$ 日で利尿がつきらくにはなったが咳、痰が つつくので $\mathrm{H}_{2}$ 6郄門、 $\mathrm{H}_{3}$ 7少海の低周波通電15 分を週 1 回併用したところ、はあはあするのが なくなり、計14回でうちきった。以上の二例は いずれも老人性のうっ血性心不全であるが、郄 門、少海の置針低周波通䉓がよい効果をもたら している。

晋血性心疾患：てれについては日本良導絡自 律神経誌に度々発表しているので詳しくはみて 頂きたいと思います。良導絡調整はむろんの 事、基本治療点 I、I 型をやって 居き、心俞 $\mathrm{F}_{4} 48$ 、硕陰俞 $\mathrm{F}_{4} 50$ の置針15分、ないしは雀啄 50〜60回をゆっくりやります。ただしての際 $\beta$ 一ブロッカーのインデラルを使用して居ります と効果がありません。

不整脈：その原因が何であれ期外収縮は郄 門、少海の置針むしくは低周波通電 15 分行う 
と、3 回目位加ら消失してくる。 $\mathrm{F}_{4} 48 、 \mathrm{~F}_{4} 50$ の置針雀を用いてむよい。

心房細動：除細動はむずかしいが郄門、少海 の低周波通電15分を週 $1 \sim 2$ 回行うと全身状態 がよくなり軽い心不全はとれてくる。

発作性上室性頻拍：郡門、少海、心俞、厥陰 俞の置針15分で大変楽になるが、ジギタリス、 或いはアシサリンの静注を併用するとよい。私 はこの様な症例はいつ起るかわからないので頓 服を次の様な妈方で与え、発作時には飲用して ねむらせるととにしている。リスモダン $1 \mathrm{Tab}$

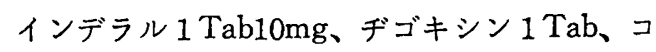
ントール $20 \mathrm{mg}$ を一方として（カクテル頓服） 持たせておくことにしている。

§ 片麻瘏：全身のEAP治療と、麻痺側の低 周波置針を週 1 回併用しているが10年以上毎週 1 回通院している症例むある。片麻疸の治療に ついては別に機会を得てまとめてみたいと思っ ている。

\section{$\S$ 上部頸椎症候群}

づつう、肩とり、めまい、はきけ等の症状は 急性、慢性をとわず、頸椎のずれ、軸転のみで これらの症状をおてしてくるのでE A P 、カイ 口のよい適応症である。
症例の 1

60才 奥さんが病気入 院で心労が多く、血压がどてへ行ってあ下らな いというととで来院、B・D 200-120mmHg、 頸椎は $\mathrm{S}$ カーブ、少量の利尿降圧剂と $\beta$ 一ブロ ッカーを用い頸椎の治療を併せて行った。1カ 月後の頸椎カーブは改善されて居り、B・D160 $-90 \mathrm{mmHg}$ にコントロールされている。 症例の 2 50才 主婦 高血圧症 十左心室肥大、S57年10月来院。ひどい動悸、 胸痛、息苦しさの発作で救急車入院するてと数 回、その際 B・D 220-130mmHg にあがる。 来院時 B・D 191-109mm、レントゲン所見 では、側弯及び腸骨偏位、頸椎 Sカーブ、であ り、骨盤の調整と頸椎の治療を併用し、降圧利 尿剂 $1 \mathrm{Tab} /$ 日、 $\beta$ ーブロッカー $3 \mathrm{Tab} /$ 日、 2 週間後 B・D 170-107mmHg、11月 8 日、約 1カ月後よくねむれるようになり、B・D140一 $96 \mathrm{mmHg}$ 、現在 B・D 133-94mmHg で頸椎 カーブは $\mathrm{S}$ 型より垂直型に改善されているし、 いきいきと仕事にはげんでいる。

\section{§ むすひ}

日常よくあつかう循環器族患の良導絡治療に ついてその取穴部位、頻度等について 概説し た。

\section{Summary}

\section{Ryodoraku and circulatory-organ-disease}

I had a outline on Ryodoraku Therapy of circulatory-organ-diseases.

Ryodoraku Therapy is very usefull for these diseases with combination of drug therapy. 